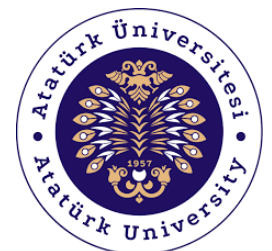

Atıf/Citiation
Doğu Coğrafya Dergisi

Haziran-2020, Yıl: 25, Sayı: 43, Sayfa: 111-122

Eastern Geographical Review

June-2020 Volume: 25, Numbers: 43, Page: 111-122

DOİ: https://doi.org/10.17295/ataunidcd.712007

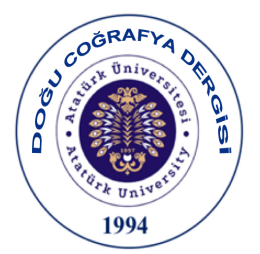

Deniz,T., Aydın,K.,(2020), Somut Kültürel Miras Örneği: Ovacık (Karabük) Kışla Köyü Su Değirmeni. Doğu Coğrafya Dergisi 25(43), 111-122

\title{
SOMUT KÜLTÜREL MİRAS ÖRNEĞİ: OVACIK (KARABÜK) KIŞLA KÖYÜ SU
} DEĞİRMENİ

Sample of Concrete Cultural Herıtage: Ovacık (Karabük) Kısla Village Water Mill

Doç. Dr. Taşkın DENIZ ${ }^{1}$

Kemal AYDIN²

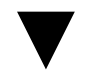

$\ddot{O} z$

Turizm ve kültürel miras kapsamında ele alındı̆̆ında somut kültürel miras unsurlarının hızla yok olmaya başladığ bugün bu unsurları yaşatmaya çalışanların tespit edilerek kendileri ile görüşülmesi, aktardıkları bilgilerin yazılı ve sesli olarak kayıt altına alınması, kültürel miras unsurlarımızın unutulmaması, yeni nesillere aktarılması ve böylece sürdürülebilir kılınmaları açısından mutlak önem taşımaktadır. Bu çalışmada, kültürel mirasın önemli örneklerinden olan su değirmenlerinin kökeni ve tarihi gelişimi ele alınmış, Karabük ili Ovacık ilçesi Kışla Köyü örneğinde bu değirmenlerin kuruluş, işleyiş ve yapısal özelliklerine değinilmiş, atıl vaziyete gelmesinin sebepleri irdelenmiş, kırsal miras unsuru olarak korunması ve gelecek nesillere taşınabilmesi için kayıt altına alınmıştır.

Araştırmada ilişkilerin anlamını ve türünü keşfetmek için gözlemlerin sayısal olmayan bir biçimde incelenmesi ve yorumlanmasını ifade eden nitel araştırma yöntemi ve verilerin toplanmasında mülakat (görüşme) tekniği kullanılmıştır. Değirmen kalıntıları ve değirmen sahibi incelenerek fotoğraflar ile belgelenmiştir. Ayrıntılı literatür taraması yapılarak bu çalışmanın bilimsel bir tabana oturtulması sağlanmıştır. Sonuç itibari ile araştırma; mülakat tekniği ile elde edilen bulguların teorik bilgilerle birleştirilmesine dayanan yorumlamalardan oluşmaktadır.

Anahtar kelimeler: Somut Kültürel Miras, Karabük, Ovacık, Kışla Köyü, Değirmen

\section{Abstract}

When it is considered within the scope of tourism and cultural heritage, the concrete cultural heritage elements have started to disappear rapidly and today, those who try to keep these elements alive are identified and discussed with them, recording the information they transmit in written and sound, not forgetting our cultural heritage elements, transferring them to new generations and thus making them sustainable. is important. In this study, the origin and historical development of water mills, which are important examples of cultural heritage, were discussed, the establishment, operation and structural

\footnotetext{
1 Karabük Üniversitesi Safranbolu Turizm Fakültesi, taskindeniz@karabuk.edu.tr, Orcid ID: 0000-0003-12935404
}

${ }^{2}$ Karabük Üniversitesi Safranbolu Turizm Fakültesi YL Öğrencisi, ka25@,hotmail.com, Orcid ID: 0000-00022869-023X 
features of the mills in the village of Ovacik district of Karabük province were examined, the reasons for their idle status were investigated, and they were preserved as rural heritage elements and carried to future generations. were recorded.

In the research, qualitative research method, which refers to the non-numerical examination and interpretation of observations to discover the meaning and type of relationships, and the interview (interview) technique was used to collect data. Mill remnants and mill owner are examined and documented with photos. In addition, a literature review was made to put this study on a scientific basis. Research as a result; it consists of interpretations based on combining the findings obtained with the interview technique with theoretical information.

Keywords: Concrete Cultural Heritage, Karabük, Ovacık, Kışla Village, Mill 


\section{1- Giriş}

Kırsal Yerleşme; temel ekonomik faaliyetlerin tarım, hayvancılık, ormancılık ve balıkçılık olduğu, köyden küçük ve köye bağlı yerleşmeler, köyler ve kasabalardan oluşan, köyün fonksiyonel etki sahası içerisinde kalan ve köylü ailelerin ekonomik yararlanma alanları olarak tanımlanabilecek, gerek işlevleri gerekse de coğrafi mekândan yararlanma süresi özellikleri bakımından şehir yerleşmelerinden farklılık gösteren yerleşmelerdir. Kırsal yerleşmelerde nüfusun çoğunluğu tarım ve hayvancılık ile uğraşmaktadır. Kırsal ve şehirsel yerleşmelerin sınıflandırılmasında kullanılan nüfus ölçütü ülkeden ülkeye değişmektedir. Bu tür yerleşmelerde nüfus ölçütünün $5.000,10.000$ ve 20.000 şeklinde kullanılmasına yönelik görüşler vardır. Kırsal yerleşmeler, yerleşmedeki ailelerin yerleşme sahasından yıl boyu yararlanma süresine göre geçici ve sürekli olmak üzere 2 gruba ayıllr. Yayla, mezra, kom, ağıl, bağ evi, değirmen, güzle ve dalyan yerleşmeleri "geçici kırsal yerleşme"; mahalle, köy, çiftlik ve kasaba yerleşmeleri "sürekli kırsal yerleşme" olarak kabul edilir. Ancak bugün çoğu kırsal yerleşme coğrafi bölgeye göre geçici ya da sürekli özelliği gösterebilmektedir.

Kırsal yerleşmelerde temel besin kaynaklarımızdan olan mısır ve buğdayın una dönüştürülmesi, hayvanların yemlerinin ögütülmesinde tarihi süreçte en fazla kullanılan yapıların başında su değirmenleri gelmektedir. Bu nedenle su değirmenleri, kırsal yerleşmelerde yaşayan insanların ekonomik faaliyetlerinde ve beslenmelerinde vazgeçilmez bir aracı olmuştur. Su değirmenleri, gerek konumları gerekse de inşa tarzıyla bulundukları sahadaki coğrafi koşulları yansıtan somut kültürel miras örneklerindendir.

Su değirmeni; buğday veya mısır tanelerinin öğütülerek una dönüştürülmesi amacı ile su yanına inşa edilmiş yapılardır. Kuruluş yerinin seçiminde suya ve yola yakınlık önemli rol oynar. Akarsu ile değirmen arasında değirmen için ihtiyaç duyulan suyun taşınabilmesi amacı ile "ark (hark, oluk, bend)" adı verilen su kanalı kazılır. Ark sayesinde değirmene ulaşan suyun, değirmende kontrollü şekilde kullanılabilmesi için, değirmen duvarından içeriye girmeden önce ahşap, plastik ya da metal borulardan oluşturulmuş, arktaki suyun istenildiği takdirde farklı yönlere aktarılmasına olanak sağlayan diğer bir ifade ile değirmeni durdurmak için çarka püskürtülen suyun önünü kesmeye yarayan düzeneğe "savak (kesecek)" adı verilir. Savak sayesinde değirmenin ihtiyaç duyduğu su miktarı ayarlanabilmekte, değirmenin çalıştırılmadığı zamanlarda arktaki suyun boş araziye salınarak arkın boş kalmasına imkân sağlanabilmektedir. Savak ile domuzluk bölümündeki değirmen çarkı arasında su akışını sağlamak için $45^{\circ}$ açı ile kazılmış üstü açık, genellikle dikdörtgen şekilli su arkı "seğirdim (arkuru oluk, düz oluk)", seğirdime döşenmiş boru ise "cebri borusu" olarak ifade edilir. Çarka doğru daralan cebri borusu en dar noktasına (fison, fism, püskürtme ucu) ulaştı̆̆ zaman taşıdığı suyu basınçla birlikte domuzluk kısmında yer alan su haznesinin önündeki çarka doğru vurdurarak çark dişlilerini hızla döndürür. Bu da çarkın bağlı olduğu mili (aksonu) ve milin diğer ucunda yer alan değirmen taşlarını (dink, ağırşak) çevirir. Suyun değirmen binasına girdiği, enerjisini çarka vererek çarkı çalıştırdığı ve suyun dışarı atıldığ1 (genelde alt katta çarkın bulunduğu) bölüme "domuzlukdonuzluk" adı verilir.

Değirmende öğütülmeye getirilen tahılın boşaltıldığı kısma "sepet-tekne-tahıl teknesi-tahıl ambarıyüklük-tanelik", sepetteki tahıl tanelerinin döküldüğü hazneye "kaşık-kepçe", kaşığı hareket ettiren (titreştiren) parçaya "salınaç", kaşıktaki tahıl tanelerinin üst değirmen taşına düştüğü kanala ise "boğaz-şeytan teknesi-alt tekne" adı verilir. Üstteki değirmen taşı (dönen taş) dönerken, alttaki değirmen taşı (taban taşı) sabittir. Dönen taş ile taban taşı arasına düşen daneler parçalanmak suretiyle elde edilmek istenen ürüne dönüşür. Değirmen taşlarının ortasındaki delik "boğaz", boğazdan geçen ve değirmen taşlarını döndüren demir ise "baltacık" olarak ifade edilir. Taşların boğaz genişliği ortalama $15 \mathrm{~cm}$ olup taşın büyüklüğüne, alt veya üst taş oluşlarına göre değişir.

Değirmende alt ve üst olmak üzere iki ayrı taş vardır. Yatay olarak yerleştirilen değirmen taşlarından alt taş 40-45 cm, üst taş ise $30 \mathrm{~cm}$ kalınlığında olup çapları $120 \mathrm{~cm}$ kadardır. Değirmen taşlarının bulunduğu bölümün kenarında değirmen taşlarını temizlemek, kırılan ya da dişlenmesi gereken değirmen taşların değiştirmek gibi işler için gerektiğinde değirmen taşlarının kaldırılması için kaldıraçlar (caraskal) yer alır. Değirmen taşlarının çevresindeki metal çemberler (bilezikler) hem üst taş dönerken öğütülen unun etrafa savrulmasın önlemek ve çıkarılan unun alt tahıl ambarına aktarmak hem de hızla dönen taşların kırılmasını önlemek için yapılmıştır (Ceylan, 2014:73,76).

Öğütülen un, yem ve bulgur "unluk" adı verilen ahşap bölmede toplanır (Fotoğraf 1). Unluk bölmesi dışında taşların arasında kalan atıl durumdaki temiz olmayan unlar ise, örneğin Konya'da, "yorak" olarak ifade edilir. Değirmen, değirmencinin (hakçının) kaldığı ve kullandığı odalar ile öğütme işleminin gerçekleştirildiği düzeneğin kurulu olduğu yer (işlik) almak üzere iki ana bölümden oluşur.

Osmanlı Devleti'nin son döneminde ve cumhuriyetin ilk yıllarında Anadolu'da değirmenlerin kullanıldığı son yerleşmelerin başında Karabük iline bağlı ilçeler ve köyler gelmektedir. Karabük ili Ovacık ilçesi Kışla Köyü’nde bulunan ancak günümüzde çalışmayan su değirmeni, yöresel yapı tarzına uygun inşa edilmiştir. 
Ancak zamanla değişen ekonomik ve teknolojik gelişmelere uyum sağlayamamış ve işlevini yöredeki elektrikli değirmenlere kaptırmış, bu sebeple bir süre asıl amacının dışında hayvan barınağı olarak kullanılmış ve bugün yok olmaya yüz tutmuştur.

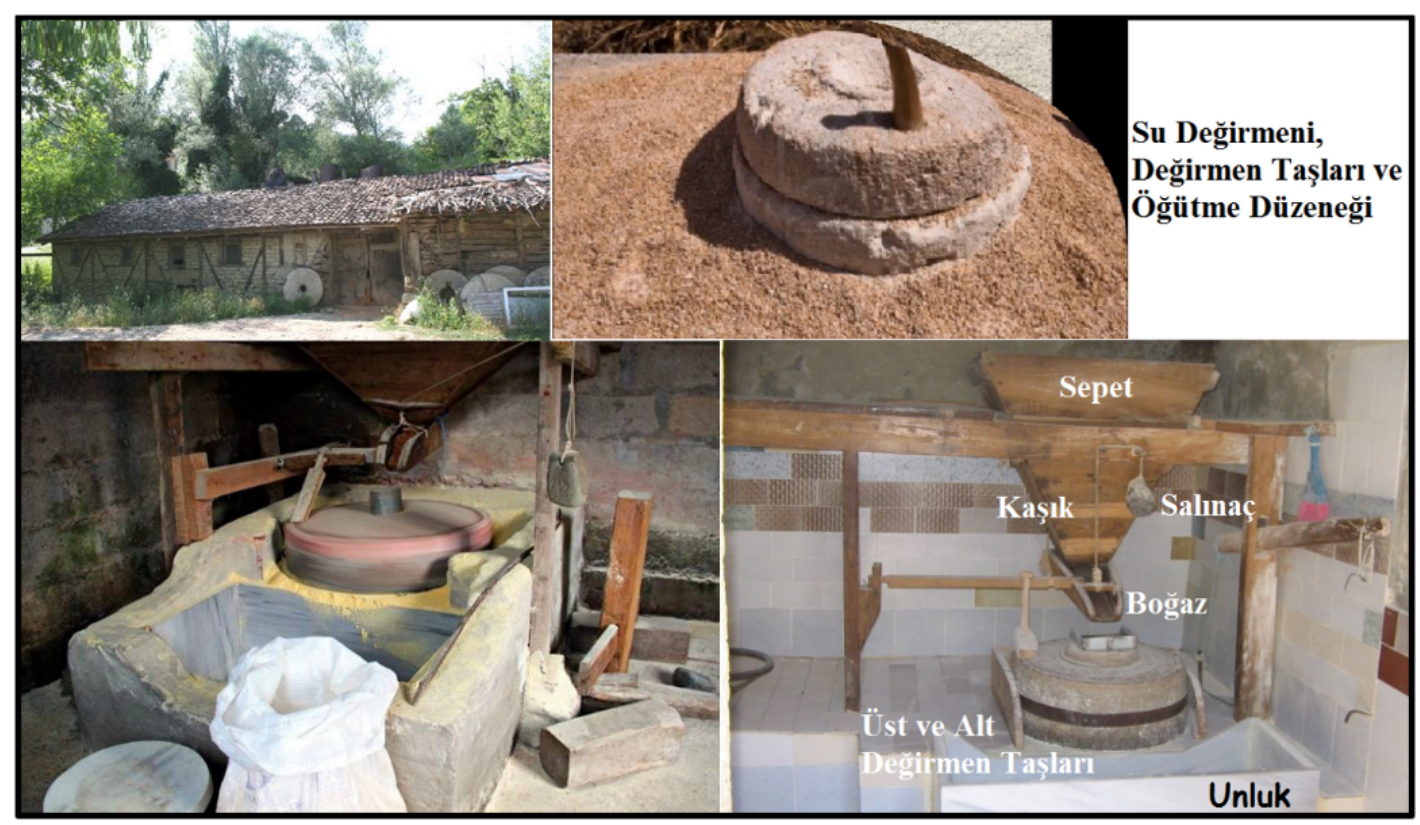

Fotoğraf 1: Su Değirmeni Genel Görünümü ve Temel Bileşenleri

\section{2- Literatür}

Değirmenlerin ilk olarak kullanılması milattan önceki zamanlara dayanır. M. Ö. 200'lü yıllarda Anadolu'da Pontuslular ve Frigyalılar tarafından ilk rüzgâr değirmenlerinin kullanıldığı düşünülmektedir. Avrupa'da M. Ö. I. Yüzyılın başlarından itibaren görülen su değirmenleri ise ortaçağ boyunca bilhassa 10.-14. Yüzyıllar arasında Kuzeybatı Avrupa'da yaygınlaşmıştır. Türklerde ise ilk rüzgâr değirmenlerine Asya Hun Devleti (M. Ö. 3. - M. S. 3. Yüzyıl) zamanında rastlanılsa da Köktürklerde, Uygurlarda, Kırgızlarda ve Hazarlarda rüzgâr değirmenleri ile ilgili unsurlara rastlanmaktadır. Günümüz anlamında su değirmenlerinin kullanımı ise yerleşik hayata sahip Uygur Devleti’nde gerçekleşmiştir (Ögel, 1989:50,69,208,226 ; Wikander,2000:396). Ekonomik yaşantının vazgeçilmez bir unsuru olan rüzgâr değirmenleri zamanla coğrafi yapıya uyum sağlayan beşerî kurumlara dönüşmüşlerdir. Su değirmenleri daha sonra icat edilmiş ve üretim sürecine eklenmişlerdir. $\mathrm{Su}$ değirmenlerinin çalıştırılması için debisi yüksek olan su kaynaklarına ihtiyaç vardır. Bu nedenle su değirmenleri akarsu kenarlarına konuşlandırılmıştır. Osmanlı Devleti döneminde su değirmenlerinin sanayi kuruluşu olarak kabul edilip değirmenlerden vergi alındığı, döneme ilişkin tahrir defterlerindeki kayıtlardan anlaşılmaktadır (Birici, 2007:99).

Önceleri insan ya da hayvan gücü ile çalıştırılan değirmenler, suyun gücünün farkına varılmasıyla beraber su ile çevrilir hale gelmiştir. Basit yapılı su değirmenlerinin Anadolu'daki ilk örneklerine Urartular'da rastlanmaktadır. Daha sonra Anadolu'da kurulan tüm medeniyetler tarafindan Anadolu'nun yeterli su kaynakları bulunan hemen her yerinde su değirmenleri inşa edilmiştir. 20. Yüzyıla gelene kadar su değirmenleri aktif olarak kullanılmış, daha sonra su gücünün yerini dizel veya elektrikli motorlar almıştır (Dündar vd, 2017:163). Su değirmenleri Anadolu'da bir şahsa ait veya bir vakfa bağlı yahut da köyün ortak malı olarak işletilmektedir. Köyün ortak malı olarak işletilen değirmenlerin bir kısmında ise değirmenler, köy ihtiyar heyeti tarafından maaş karşılı̆̆ tutulan bir değirmenci tarafından çalıştırılmaktadır. Köyün ortak malı olan değirmenlerin bazılarında ise, una ihtiyacı olan köylü kendi buğdayını kendi öğütmektedir. Bu tür su değirmenlerinde değirmenin onarım işi imece usulüyle yapılmaktadır (Demir, 2003:153-154).

Su değirmenleri Anadolu'da 20. Yüzyılın sonlarına kadar varlığını sürdürmüştür. Ancak makineleşme, gelişen teknoloji, zaman içerisinde artan nüfus etmenleri gibi sebeplerden dolayı su değirmenleri yerlerini modern üretim tesislerine bırakmıştır. Yaşanan olumsuzluklara rağmen Anadolu'da nadir de olsa arazi yapısı ve coğrafi nedenlerden kaynaklı su değirmenlerinin halen yaşadığı yerleşmeler bulunmaktadır. Çoğu zaman işlevselliğinin dışında kullanım alanlarına dönüştürülen su değirmenleri, otantik yapısıyla toplum hayatında lokanta, kahvehane, kafe, konaklama alanı pansiyon gibi işlevselliklere büründürülerek, gelecek zamanlarda varlığını bu unsurlara mekân olarak sürdüreceğe benziyor (Gürses vd., 2007:645). 


\section{3- Yöntem}

Osmanlı Devleti'nin son döneminde ve cumhuriyetin ilk yıllarında Anadolu'da değirmenlerin ön planda olduğu yerleşmelerin başında Karabük ili Ovacık ilçesi Kışla Köyü gelmektedir. Bu doğrultuda araştırmanın amacını, Karabük iline bağlı Ovacık ilçesi Kışla Köyü’nde değirmenlerin ve değirmenciliğin sosyo-ekonomik yaşamdaki yerinin ve öneminin açıklanması oluşturmaktadır. Araştırmanın evreni yok olmaya yüz tutmuş değirmenler ve değirmencilik, örneklemi ise Ovacık ilçesi Kışla Köyü’ndeki mevcut değirmendir. Araştırmada ilişkilerin anlamını ve türünü keşfetmek için gözlemlerin sayısal olmayan bir biçimde incelenmesi ve yorumlanmasını ifade eden nitel araştırma yöntemi ve verilerin toplanmasında yapılandırılmamış bireysel mülakat (görüşme) tekniği kullanılmıştır. Değirmen kalıntıları ve değirmen sahibi incelenerek fotoğraflar ile belgelenmiştir. Ayrıca literatür taraması yapılarak bu çalışmanın bilimsel bir tabana oturtulması sağlanmıştır. Sonuç itibari ile araştırma; mülakat tekniği ile elde edilen bulguların teorik bilgilerle birleştirilmesine dayanan yorumlamalardan oluşmaktadır.

\section{4- Ovacık İlçesi}

Karadeniz Bölgesi Batı Karadeniz Bölümü’nde Karabük iline bağlı bulunan Ovacık ilçesi; Karabük ilinin güneydoğusunda, Çankırı ilinin kuzeybatısında olup batıda Eskipazar, doğuda Araç (Kastamonu), kuzeyde Safranbolu (Karabük), kuzeybatıda Karabük il merkezi, güneyde Çerkeş (Çankırı) ve Atkaracalar (Çankırı) ve güneydoğuda Bayramören (Çankırı) ile komşudur (Harita 1).

Ovacık, $41^{\circ}$ kuzey paraleli ile $32^{\circ}$ doğu meridyeni arasında yer almaktadır. İlçenin kurulu olduğu arazi, IV. Jeolojik zamanda teşekkül etmiş genç yaşlı saha olduğundan dolayı 1. Derece Deprem Sahası'dır. Nitekim ilçenin bulunduğu sahada 1944 yılında çok büyük bir deprem (Bolu Gerede Depremi) gerçekleşmiştir.

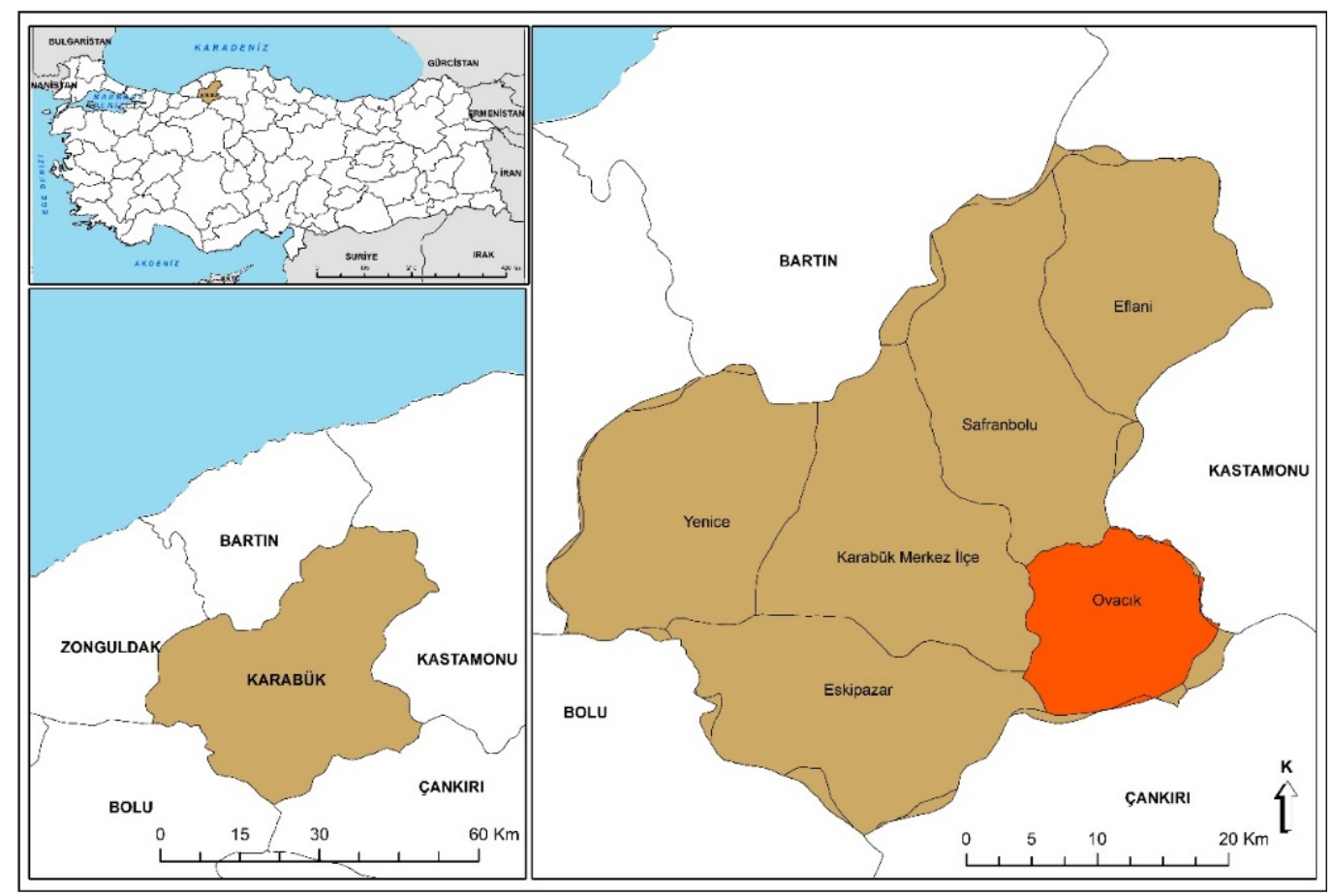

Harita 1: Ovacık İlçesi Lokasyon Haritası

Ovacık ilçesinin deniz seviyesinden yüksekliği (rakımı) 1100 m., yüzölçümü 393 km²'dir. Ilgaz ve Köroğlu dağlarının devamında yer alan ilçe arazisinin en yüksek yeri Boduroğlu Yaylası ve Kıraçtepe olup rakımı yaklaşık 1400 m’dir. Ayrıca ilçe sınırları içerisinde ve çevresinde Göllü, Kireçli Su, Çatak ve Belen yaylaları ile Göktepe, Ahmetler, Kocadağ, Dazkırıtepe, Çam doruğu, Kavaklar ve Erenler dağları bulunmaktadır. İlçenin kuzeyinden akan Soğanlı (Melan) Çay’ı boyunca oluşmuş olan Melan Ovası, ilçenin en önemli tarım arazisini oluşturmaktadır. Toplam yüzölçümünün \% 67'si ormanlık alan (252,69 ha.), \% 13'ü tarımsal alan (5000 ha), $\%$ 18'i tarım dışı alan (7000 ha) ve \% 2'si çayır ve meralıktan (600 ha) oluşan Ovacık ilçesinde genel itibari ile ormanlık, dağlık ve dağınık bir arazi yapısı görülmektedir. Ormanlık alanlarda karaçam, sarıçam, meşe, kayın, fındık, kuşburnu ve kızılcık türleri ön plandadır (Ovacık Belediyesi, 2020). 
İlçe sınırları içerisindeki en uzun akarsu Soğanlı (Melan) Çayı olup bu çayın yanı sıra kışları debisi yükselen ancak yaz sıcaklığı ve kuraklığı ile kuruyan küçük çaplı pek çok dere bulunmaktadır. Soğanlı (Melan) Çayı, Çankırı iline bağlı Çerkeş - Atkaracalar - Bayramören ilçelerinin topraklarından geçmekte olan Uluçay (Gerede, Koltuk) ile birleşerek ilçenin kuzeyinden geçmekte olan Araç Çayı'na katılır ve Filyos'dan Karadeniz'e dökülür. İlçede Karagöl gölü ile Sülük ve Hatipoğlu göletleri bulunmaktadır. Ovacık ilçesinde kısmen Karadeniz iklimi ve kısmen karasal iklim özellikleri görülmektedir. İlçede kış mevsimi soğuk ve kar yağışlı, yaz mevsimi serin ve yağışlı geçmektedir. Yıllık ortalama yağış miktarı 600 mm'dir (Ovacık Belediyesi, 2020). Karagöl gölü, göletler ve Kent Ormanı en önemli rekreasyon alanları olarak ön plana çıkmaktadır.

Tarihi belgeler incelendiğinde Paflagonya sınırları içerisinde kalan Ovacık tarihi süreçte Hitit, Frigya, Lidya, Galat, Roma, Bizans ve Anadolu Selçuklu egemenliğinde kalmış, 1350 yılında Osmanlı kontörlüne girmiş, 1416 yılında Çelebi Sultan Mehmet tarafından Çankırı Sancak Beyliği bünyesindeki Çerkeş’e bağlamıștır. 16. Yüzyıldaki belgelerde (1530 tarihli ve 438 sayılı Tahrir Defteri) ise Ovacık ve çevre köylerin Bolu Sancağı'na bağlı Viranşehir Nahiyesi’ne Ulak Divanı olarak bağlı olduğu anlaşılmaktadır. Ancak 1864 "Vilayet Nizamnamesi" sonrasında Ulak önce 1867 yılında Kastamonu ili Viranşehir Livası'na ve 1868 yılında Çankırı Sancağı'na bağlanmıştır. Osmanlı tarihçileri Ali CEVAT' ve Şemseddin SAMİ'ye göre Kastamonu 1869 Tarihli Salnamesi'nde Ovacık'ın adı "Ulak" olarak ifade edilmiştir. O dönemlerde katırcıların ve kervancıların Amasra Limanı - Çankırı - İç Anadolu ticaret yolunun geçiş güzergâhı Çerkeş - Ovacık - Safranbolu - Bartın istikametini takip ettiğinden dolayı Ovacık önemli bir ekonomik güce sahipti. 1877 tarihli Şuray-1 Devlet'e ait bir defterde Ulak ve çevresi nahiye olarak belirtilmiştir. Ovacık, Çankırı ili Çerkeş Kazası’na bağlı bucak olarak 1959 yılına kadar varlığını sürdürmüş, 01.04.1959 tarihinde Çankırı ilinin ilçesi olmuştur. 1995 yılında ise Karabük'ün 78. il olması ile birlikte Ovacık, Karabük ilinin beş ilçesinden biri yapılmıştır (Ovacık Belediyesi, 2020). İlçe sınırları içerisinde Pürçükören Köyü Karakoyunlu Mahallesi'nde Lidya dönemine ait kaya mezarları (Kurutma Kayası, Gerdek Boğazı, Karain) ve gözetleme kulesi; tarihi camiler (Abdullar Köyü, Bayalı Köyü, Çatak Köyü) ve türbeler (Yerli Baba, Can Baba, Musa Efendi) bulunmaktadır.

\section{5- Kışla Köyü}

Ovacık ilçesine bağlı Kışla Köyü, rakımı fazla olduğundan dolayı hava koşullarının daha sert geçmesi sebebi ile kış mevsimini geçirmek için Koltuk Çayı kenarında oluşan alüvyal ovaya inen Erkeç Köyü ve Belen Köyü sakinlerinin zamanla kalıcı olarak buraya yerleşmesi sonucunda oluşmuş bir yerleşmedir. Köy sakinleri, yeni oluşturdukları bu köyü "Kışla Köyü " olarak isimlendirmişlerdir (KK1, KK2) (Fotoğraf 2).

770 m rakıma sahip Kıșla Köyü, Ovacık ilçe merkezine 7 km, Karabük il merkezine ise yaklașı 36 km uzaklıkta bulunmaktadır. Avlağıkaya, Koltuk, Taşoğlu, Erkeç, Eğberler ve Belen köyleri ile komşudur. 2019 yılı nüfus sayımına göre nüfusu 221 olan köyde ilkokul, sağlık ocağı ve sağlık evi bulunmaktadır. Elektrik ve sabit telefon vardır, içme suyu ve kanalizasyon şebekesi mevcut olup, ulaşım asfalt bir kara yolu ile yapılmaktadır. Cingiller, Kahveci ve Pazaryeri olmak üzere üç mahalleye sahiptir.

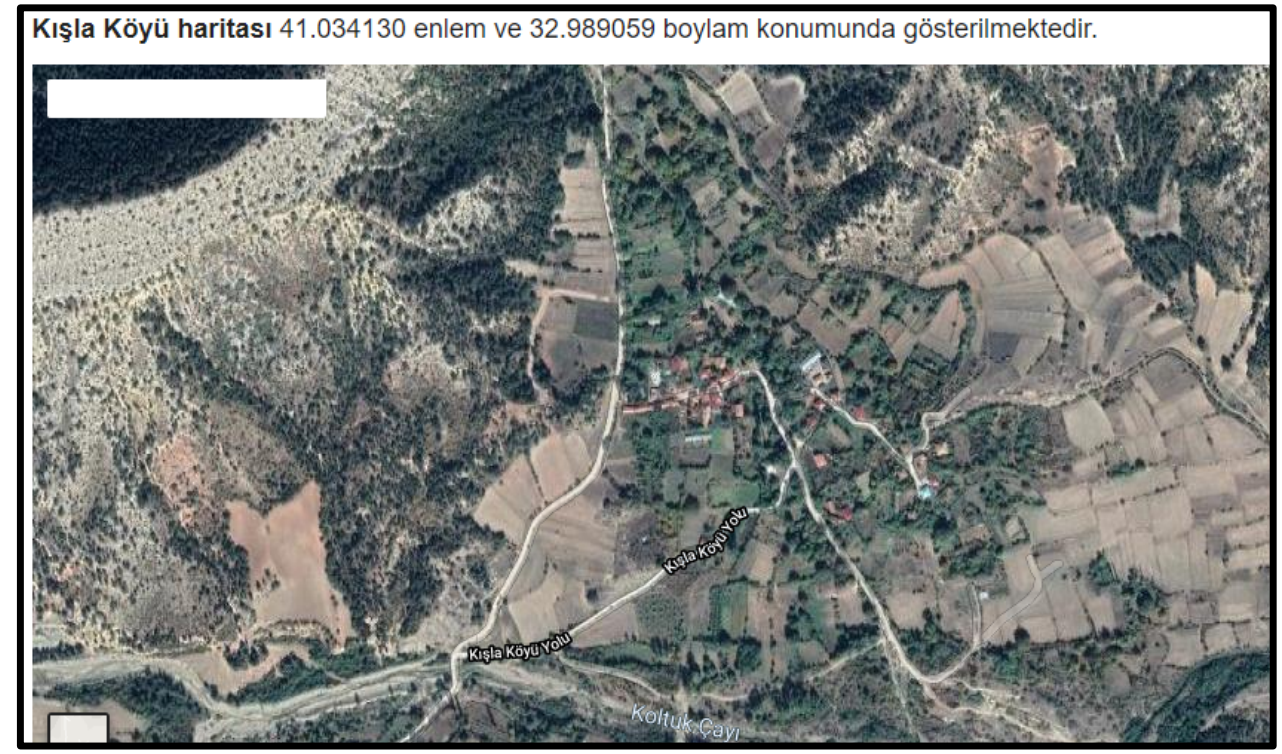

Fotoğraf 2: Kışla Köyü Uydu Fotoğrafi 


\section{6- Kışla Köyü Değirmeni}

Kışla Köyü sakinleri geçimini arıcılık, tarım ve hayvancılıktan karşılamaktadır. Köyde buğday ve mısır ekimi yapılmaktadır. Üretilen buğdayın bir bölümü köylülerin kendi un ihtiyaçlar için ayrılmaktadır. Ayrılan buğday bugün çevre ilçelerdeki elektrikli değirmenlerde un haline getirilmektedir. Ancak 1990'lı yıllara kadar köy sakinlerini kendi ürünlerini köydeki su değirmeninde öğütmekteydiler.

Bugün atıl durumda olan su değirmeni ile ilgili mevcut bilgiler, sahibi durumundaki Alaattin KAPUCU (1960, KK1) ile köy sakinleri Naciye KAPUCU (1945, KK2), İsmail AYDIN (1950, KK3) ve İlker PAR (1976, KK4) ile yapılan mülakat (görüşme) sonucunda elde edilerek kayıt altına alınmıştır.

\section{- Bize kendinizi tanıtır mısınız Alaattin KAPUCU Bey (KK1)}

1960 yılında Klşla Köyü’nde doğdum. Çocukluğum ve gençliğim bu köyde geçti, bu köyde evlendim. Kardemir'e işçi olarak girdim ve emekli olunca şehir merkezindeki evim ile köydeki evim arasında gelip gitmeye başladım. Her sene ilkbahar mevsiminde köye geliyor, sonbahar mevsiminde şehre geri dönüyorum. Dedem zamanında ailemiz yukarıdaki köyden buraya göç etmiş ve bu köye yerleşmiş.

\section{- Kışla Köyü su değirmeninin konumu}

Su değirmenlerinin yeri seçiminde ulaşım açısından hem su kaynağına hem de yerleşim alanına yakınlığı önem taşır. Ancak Su değirmenlerinin kuruluş yeri seçiminde su kaynakları daima dikkate alınsa da suyun uzaklara kolaylıkla taşınabilmesinden dolayı bu her zaman dikkate alınmaz (Ceylan, 2014:73). Aynı zamanda değirmenin çalıştıracak olan suyun yüksekten düşmesi için su değirmenin eğimli bir arazide kurulması gerekmektedir. Bu eğimin ortalama $45^{\circ}$ olması öngörülmektedir. Nitekim Kışla Köyü su değirmeninde de bu konuya dikkat edilmiştir.

Kışla Köyü su değirmeni, TKGM (Tapu ve Kadastro Genel Müdürlügü) parsel sorgulamasında köyün yaklaşık 2 km ilerisinde Soğanlı (Melan) Çayı'nın yaklaşık 300 m uză̆ında 134/2 ada ve parselde

bulunmaktadir.

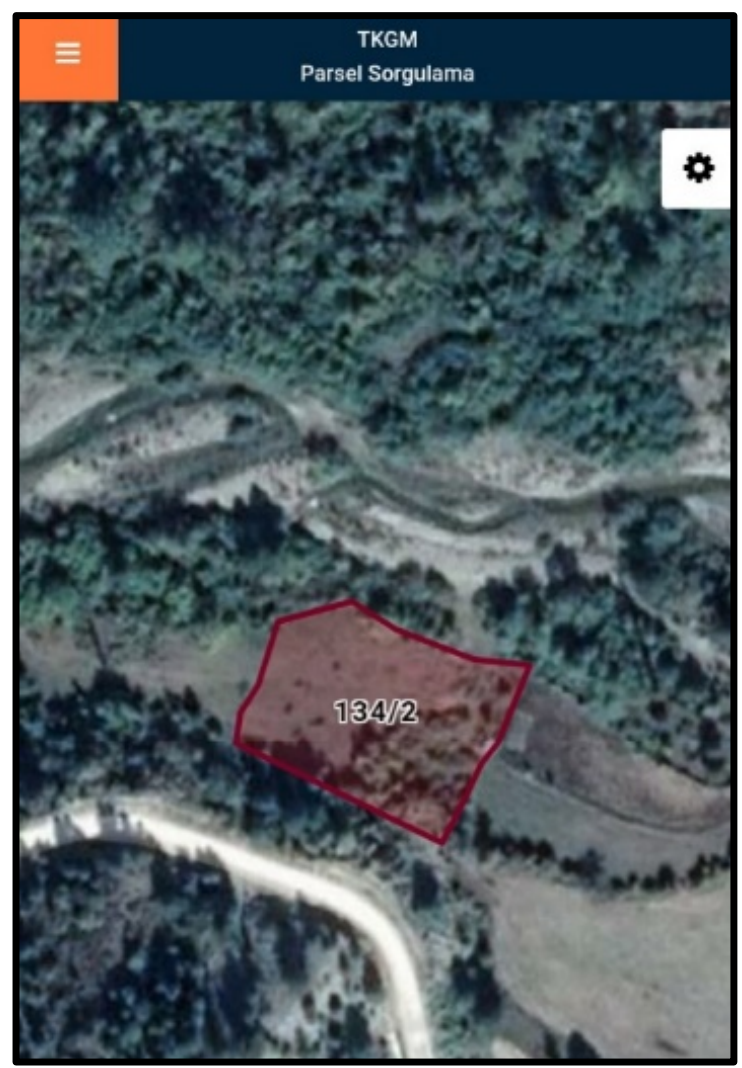

Fotoğraf 3: Su Değirmeninin Bulunduğu Ada ve Parsel 


\section{- Kışla Köyü su değirmeninin tarihi geçmişi}

Kışla Köyü su değirmeni, 1800’lü yıllarda Kışla Köyü’nün yaklaşık 2 km dışında Soğanlı (Melan) Ovası'nda Soğanlı (Melan) Çayı 'nın kenarında duvarları taş, iç kısımları ahşap, çatısı toprak bacalı olarak dedemin babası Ali Güllü tarafindan yaptırılmıştır. Su değirmeni daha sonra dedem Kamil KAPUCU'ya intikal etmiş, miras bölünmesi nedeni ile 7 ortak tarafindan işletilmiş, 1919 yılında Çanakkale Gazisi dedem Kamil KAPUCU tarafindan tamir ettirilip yeniden çalışır hale getirilmiştir (Fotoğraf 4). Dedem Kamil KAPUCU bu çevrede gazi maaşı alan ilk kişiydi. Çanakkale Savaşı 'nda săg eline şarapnel parçası gelmiş, üç parmă̆

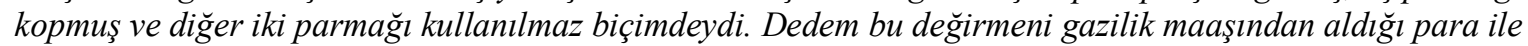
onartmış ve yeniden çalışır hale getirmiştir. İki taşlı su değirmenindeki ahşap cebir borusu, 1979 yılında Safranbolu'da yaptırılan metal cebri borusu ile değiştirilmiş ve bu yenileme sonrasında su değirmeni yine hizmet vermeye devam etmiştir (Fotoğraf 5).

Ben de Kardemir'de işe girinceye kadar değirmende çalıştım. Amcam, değirmende çalışırken vefat etti, cenazesini buradan kaldırdık. Dedemlerden duyduğumuz değirmenin önünden ayda bir posta katarı geçer Çankırı'dan gelen posta katarı değirmenin önünden İsmet Paşa 'ya çıkar ve oradan da Ístanbul'a doğru yol alırmış. Tam ayrıntısını hatırlamıyorum ama bu posta katarının bu değirmenin biraz ilerisinde soyulduğu hikâyesini dinlemiştim. Dedem Kamil KAPUCU'dan babama ve amcalarıma miras kalan su değirmeni, babam ve amcalarımızdan da bana ve amca çocuklarıma miras kaldı. Benim Kardemir'e işçi olarak girmem, diğer mirasçıların ise başka şehirlere göçmesi ve elektrikli değirmenlerin çevrede işler hale gelip daha kolay ve daha çabuk un elde edilmesine bağll olarak değirmeni cazibesini ve işlevselliğini yitiren su değirmeni kapatılarak kaderine terkedilmiş, yok olmaya bırakılmıştır. Su değirmenin taşları, değirmenin olduğu arazide atıl durumda bulunmaktadır (KK1) (Fotoğraf 6).

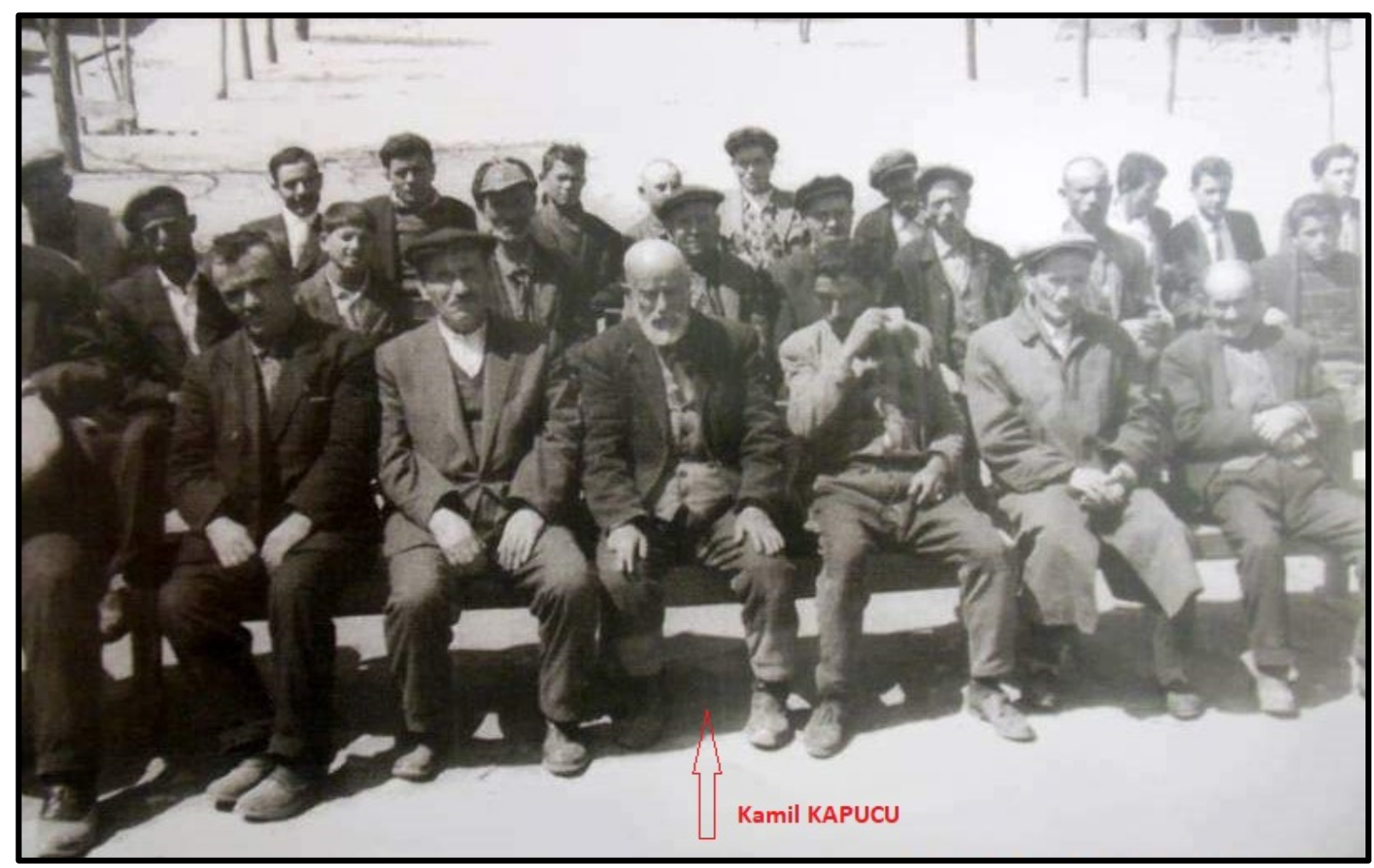

Fotoğraf 4: Kışla Köyü Değirmeni İşletmecisi Kâmil KAPUCU ve Ortakları 


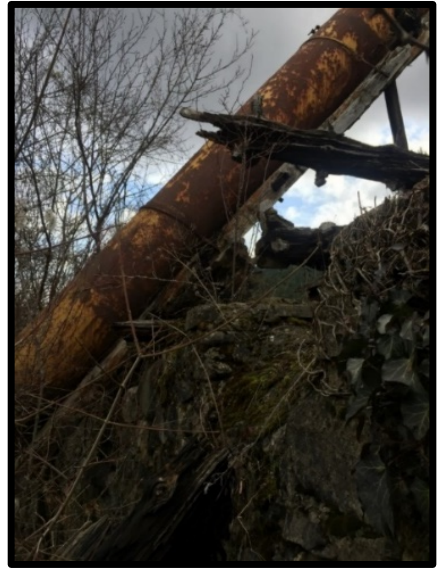

Fotoğraf 5: Kışla Köyü Su Değirmeninin

Değiştirilen Cebri Borusu

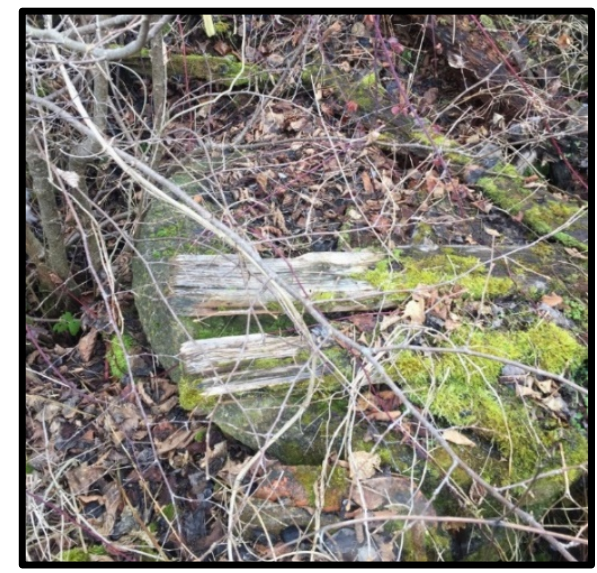

Fotoğraf 6: Kışla Köyü Su Değirmeninin

Değirmen Taşları

\section{- Kışla Köyü su değirmeninin yapısal özellikleri ve mekân düzeni}

Kışla Köyü su değirmeni 6 m $x 11$ m boyutunda dikdörtgen şekle sahiptir. Tek katl yapının duvarları taştan olup yüksekliği 2,35 m'dir. Taş duvarların üzerine belirli aralıklarla (ortalama $30 \mathrm{~cm}$ ) yatay biçimde uzun ve sağlam ağaçlar uzatılmış, ăgaçların üzeri önce çalı çırpı ile kaplanmış ve onların da üzerine toprak serilerek yapının çatısı oluşturulmuştur. Değirmenin ön kısmında bir giriş kapısı ve giriş kapısının sağında ve

solunda olmak üzere iki pencere, iç kısımda ise yan duvarlarda içeriyi aydınlatan karşıllk birer pencere

bulunmaktadır (Resim 1). Değirmenin sağında ve solunda ikişer oda bulunmaktadır. Odalardan biri

değirmencinin yaşam alanı olarak kullandığ ve kıyafetlerini değiştiği değirmenci odasıdır. Değirmenci, değirmenin aktif olduğu sürede değirmenci odasında yaşantısını sürdürürdü. Havanın soğuk olması ihtimaline karşın değirmenci odasında soba bulunurdu. Diğeri buğday ögütmeye gelenlerin bekleme ve dinlenme odası, bir diğeri sürekli ocă̆ın yandı̆̆ ve bu sayede taze demlenmiş çay içilen ve yemek yenen oda, sonuncusu ise depo olarak kullanılan odadır (KK1).

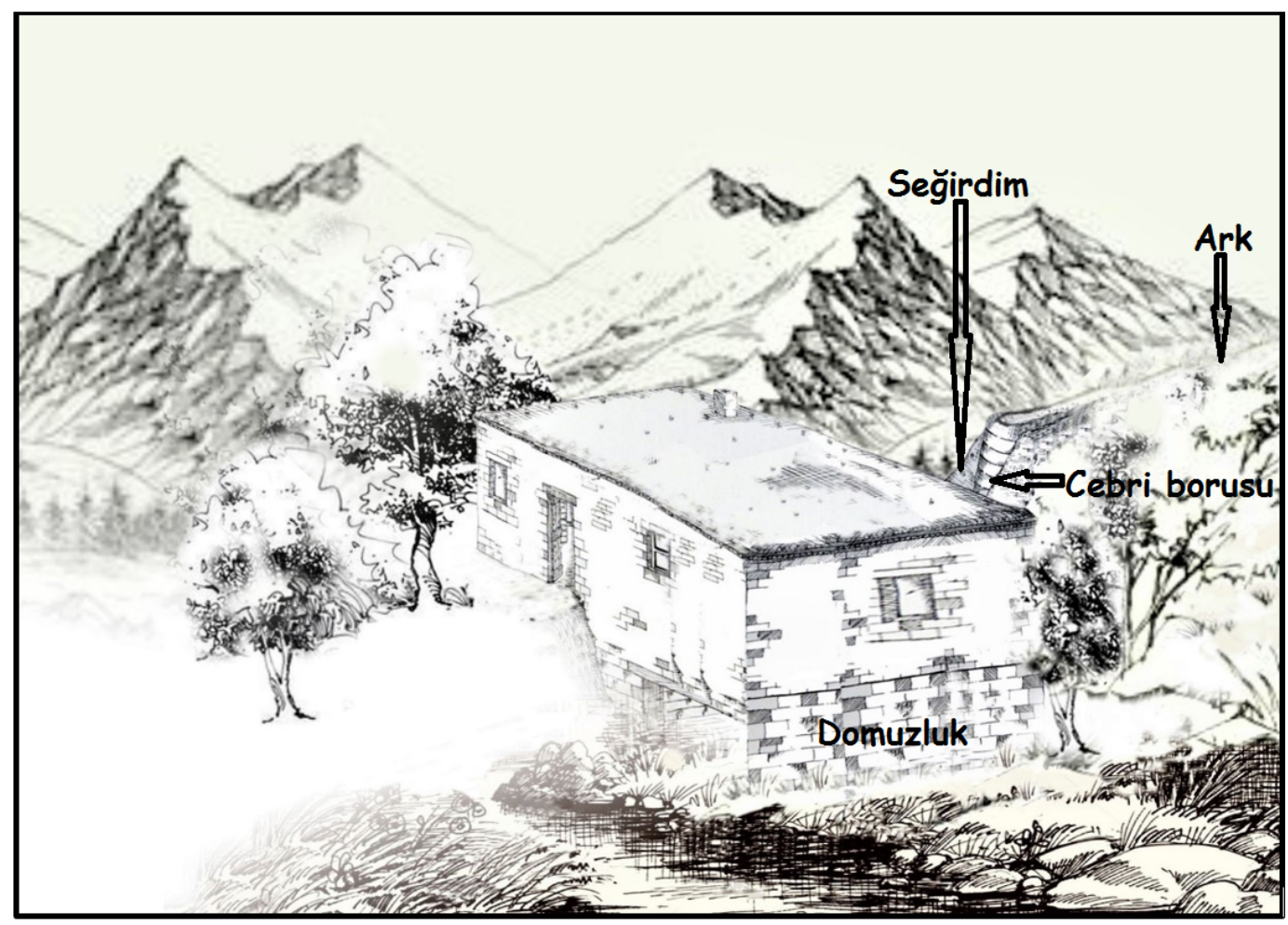

Resim 1: Anlatılan Bilgiler Işı̆̆ıında Kışla Köyü Su Değirmeninin Dış Görünümü (Temsili Çizim) 


\section{- Kışla Köyü su değirmeninin çalışma bilgileri}

Kışla Köyü su değirmeninde sonbahar mevsiminde un ögütülmeye başlanır, haziran ayının sonuna kadar üretim işlemi devam ederdi. Değirmende değirmenciler tarafindan köy sakinlerinin getirdiği ürünlerin ögü̈ülmesine ilişkin çeşitli ölçü birimleri kullanırlardı. Bu ölçü birimleri “kile” (32 kg'llk teneke), "yarım”" (16 kg'llk teneke), “şinik” (8 kg'llk teneke), “ölçek” (4 kg'llk teneke) ve "hakla-hakciyek” (1.6 kg'llk teneke) olarak ifade edilirdi (Resim 2). Değirmende ögüttüğ̈̈müz her kilenin karşıllğında $1.6 \mathrm{~kg}$ un ya da buğday (hakla, hakçiyek) alırdık. Aldığımız bu paya "değirmenci hakkl, gebiz, gabız" adı verilirdi. Genelde değirmenci hakk \% 5-\% 8 arasında değişir. Öğ̈̈̈tme sırasında üründen bir miktar fire verilir. Örneğin, 1 kg buğdaydan 800 gr un elde edilir yani yaklaşık $200 \mathrm{gr}$ kadarı ögü̈tme sırasında yitirilir. Değirmende üretilen mısır ve buğday gibi tahıllar köylülerin ekmek ve çörek gibi temel besin maddelerinin yapımında kullanılırdı.

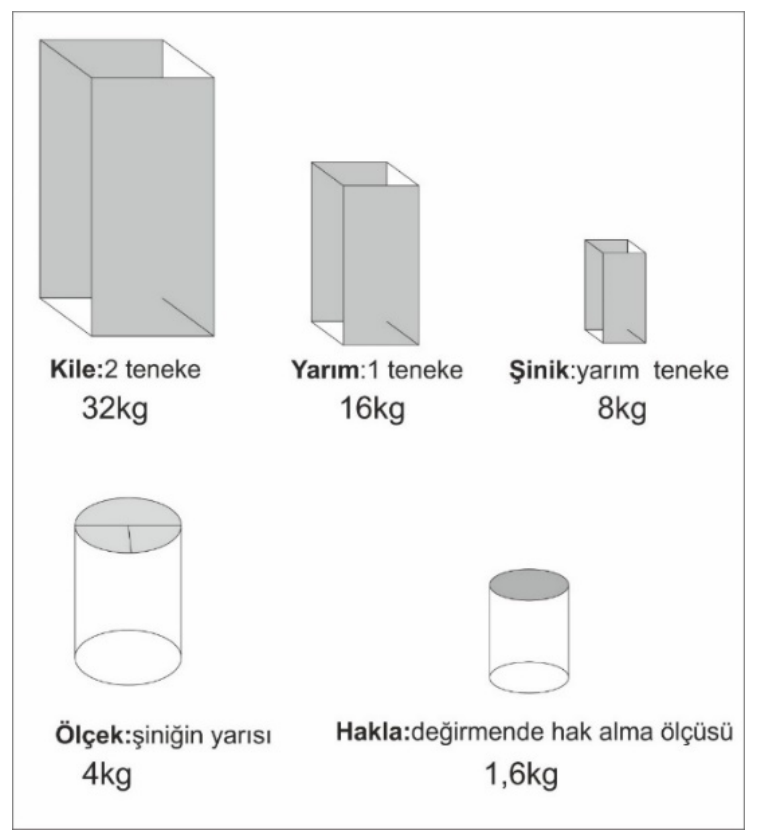

Resim 2: Su Değirmeninde Kullanılan Ölçü Birimleri (Temsili Çizim)

Buğday ya da mısır çuvallarının ă̆ır olması ve köy yerinde pek hoş karşılanmaması gibi nedenlerden dolayı değirmene gitme işini erkekler yapardı. Ĕger işleri uzun sürecekse kadınlar yemek yollardı. Çünkü köyümüze yakın olan Çankırı ili Bayramören ilçesine bağlı çevre köylerden çok sayıda insan değirmene gelirdi.

Her pazartesi köyümüzde pazar kurulduğundan dolayı genellikle pazartesi günü gelirlerdi ve bu esnada değirmende buğdayları öğ̈̈tülürken kendileri değirmenin dinlenme odasında, hayvanları da değirmenin çevresinde dinlenirlerdi. Hatta çevre köylerden değirmene gelip de bu vesileyle tanışıp evlenenler bile olurdu. Bazen parası olmayanlar değirmenciye değirmenci hakkı olarak yumurta, tavuk, kaz ya da ördek verirdi. Bir de heyelan ya da aşırı yă̆ıs sebebi ile değirmene giden ark tıkanırdı ve köylüler arkın açılması için imece usulü çalışarak arkın akmasını sağlardı. Bu değirmen sayesinde kıtlık dönemlerinde hiç yokluk görmedik, çoluk çocuk aç kalmadık çok şükür. Ancak elektrikli değirmenler çıkınca bizim değirmene gelen giden azald ve değirmen

kapandl (KK2).

Ovacık ilçesi Boyalı Köyü’nde doğdum ve Klşla Köyü bizim köye biraz uzaktı. Bu sebeple değirmene ancak firsat bulduğumuzda gidiyorduk. 1978 yılında bir gün annem evde unumuzun azaldığını ancak birkaç yoğurumluk unumuz kaldığını söyledi. Ben de buğday çuvallarımızı traktöre yükledim ve Kışla Köyü’ne gittim. Değirmene ulaştığımda çok fazla kuyruk olduğunu gördüm ve bu beni tedirgin etti. Çünkü akşam geri dönmek zorundaydım ve önceden sıra (nöbet) almamıştım. Ne yapacağımı kara kara düşünürken adını sonradan ögrendiğim yaşlı Klşla Köyü'nden bir amca (Rlfat amca) bana yaklaşarak Neden oflayıp pufluyorsun? Ne derdin var evlat? diye sordu. Ben de durumunu açıkladım ve Rıfat amca babacan bir tavırla "Dert etme evlat, sen şimdi benim nöbetimde ununu ögüt, yükle ve git” diyerek nöbetini verdi. Ne Kışla Köyü değirmeninde yaşadığım bu olayı ne den Klşla Köyü sakinlerinin misafirperverliğini hiçbir zaman unutmadım (KK3). 
1976 yllında Kışla Köyü’nde doğdum. Köydeki değirmeninin çevresi bizim için oyun alanıydı. Bir yaz mevsiminde hava çok sicaktl, 6-7 arkadaş serinlemek amact ile değirmene giden su arkinın yanina gittik ve oynamaya başladık. Arkin genişlediği bir yerde arkadaşlarımdan biri burada bir göl yaparak yüzme fikrini söyledi. Bunun üzerine arkn içerisine taş dizmeye ve suyun önüne set çekmeye başladık. Bir süre sonra akarın içerisinde su akışını durdurduk ve oluşturduğumuz küçük gölette yüzmeye başladık. Gölette eğlenirken uzaktan koşarak ve bağırarak gelen değirmenci amcayı gördük. Çünkü farkında olmadan değirmene giden suyu kesmiş ve değirmenin çalı̧̧masını durdurmuş̧uk. Değirmeni amca bize kızdl, arkı eski haline getirerek su akışını tekrar sağladı. Bu olay köyde hemen yayıl, büyüklerimiz bizimle hem dalga geçti hem de ailemizden sopamızı yedik.

Böylesine anılarımızın olduğu değirmenimizin bugün kullanılmayacak durumda olması bizleri oldukça üzmektedir (KK4).

\section{7- Sonuç ve Öneriler}

Sanayileşme ile gelen makineleşme ve inşaat alanındaki geliş̧meler, geleneksel yerel mimari örneklerinin hızla yok olmaya yüz tuttuğu hatta tamamen yok edildiği bir dönemi başlatmıştır. Şehirleşme ve büyük kentlere göç olgusu köylerin boşalmasına neden olmuş, tarım ve hayvancılık gerilemiş değirmen, samanlık, ambar ve firın gibi unsurlar işlevlerini kaybederek kaderleriyle baş başa kalmışlardır. Eski konutlar ise doğal ve kültürel özellik taşımayan betonarme yapılara yenik düşmüştür. Su değirmenleri de bu kaderden payını almış hızlı bir yok oluş serüvenine girmiştir.

Su değirmenlerinin bugün harap halde olmalarında inşa tekniği, kullanılan malzeme, harçla yapılıp yapılmaması, bir kısmının bahçe yapılırken sahiplerince yıkılması, bir kısmının malzemelerinin başka yerlerde kullanılması gibi unsurlar etkili olmuştur.

Geleneksel su değirmenlerinin korunması konusundaki temel sorunların başında bu kültür varlıklarının Türkiye yasal koruma ölçütleri içinde dikkate alınmayarak yasal koruma kapsamı dışında ve tescilsiz durumda bulunmaları gelmektedir. Bunun dışında sosyal ve ekonomik nedenlerle geleneksel değirmen ve değirmencilik kültürünün unutulması işlevsel sürdürülebilirliklerini etkilerken, kırsal mimari mirasın korunması konusundaki ekonomik ve kültürel yetersizlikler de yapısal sürdürülebilirliklerini tehdit etmektedir (Örs Çorapçıoğlu ve Ulusoy Binan, 2017:236).

Bu çalışmada, kültürel mirasın önemli örneklerinden olan su değirmenlerinin kökeni ve tarihi gelişimi ele alınmış, Karabük ili Ovacık ilçesi Kışla Köyü örneğinde kuruluş, işleyiş ve yapısal özelliklerine değinilmiş, atıl vaziyete gelmesinin sebepleri irdelenmiş, kırsal miras unsuru olarak korunması ve gelecek nesillere taşınabilmesi için kayıt altına alınmıştır.

Karabük ili Ovacık ilçesi Kışla Köyü su değirmeni de gelecekte aynı sonu yaşayacak belki de doğal olayların etkileri (rüzgâr, yağmur, erozyon) ile kalan son izleri de silinecektir. Kültürel miras açısından geleceğe taşınması için onarım görmesi ve kullanılabilir hale getirilmesi gerekmektedir. $\mathrm{Bu}$ da değirmen olmanın dışında kırsal turizm bağlamında alternatif turizm unsuru amaçlı kullanım özelliklerine sahip olmasıyla mümkün olabilir. $\mathrm{Bu}$ durum yörenin tanıtılmasına ve yerel halkı turizm alanına yönlendirerek yeni bir geçim alanı yaratabilir.

Çalışmada adı geçen tüm kaynak kişilere (KK1, KK2, KK3, KK4) teşekkür ederiz.

\section{8- Kaynakça}

Birici, S. (2007). Klasik Türk Edebiyatında Âsiyâ. Fırat Üniversitesi Sosyal Bilimler Dergisi, 17(1):97-113.

Ceylan, S. (2014). Kaybolmakta Olan Bir Kırsal Maddi Kültür Örneği: Su Değirmenleri (Ağlasun Örneği). Doğu Coğrafya Dergisi, 19(31):65-82.

Demir, N. (2003). Su Değirmenlerinin Müzelenmesi. Türkiye'de Halkbilimi Müzeciliği ve Sorunları Sempozyumu Bildirileri, Ankara: Gazi Üniversitesi THBMER Yayını: 148-163.

Dündar, O., Polat, M., vd. (2017). Zonguldak Bölgesi Su Değirmenleri ve Teknik Özellikleri. Uluslararası Katılımlı 6. Tarihi Yapıların Korunması ve Güçlendirilmesi Sempozyumu, Sempozyum Kitabı, 163-173.

Gürses, R. ve Karababa Taşkın, E. B. (2007). Anadolu'da Kaybolmakta Olan Bir Maddi Kültür Unsuru: Su Değirmenleri (Beypazarı Örneği). Uluslararası Asya ve Kuzey Afrika Çalışmaları Kongresi Bildirileri, Atatürk Kültür, Dil ve Tarih Yüksek Kurumu Yayınları:4/2, 645-677.

Ögel, B. (1988). İslâmiyet’ten Önce Türk Kültür Tarihi. Ankara: Türk Tarih Kurumu Yayınları: 89. 
Örs Çorapçıŏlu, G. ve Ulusoy Binan, D. (2017). Su Değirmenlerine Yönelik Bir Belgeleme ve Koruma Yöntemi. Megaraon Dergisi, 12(2):228-248.

Wikander, Ö. (2000). The water-mill" in Wikander (ed.), Handbook of Ancient Water Technology (Technology and Change in History 2). Leiden, Boston, Koln: 371-400.

\section{İnternet Kaynakçası}

Ovacık Belediyesi, (2020). http://www.ovacik.bel.tr/?pnum=12\&pt=Ovac\%C4\%B1k+Tarih\%C3\%A7e

[Erişim Tarihi: 03.03.2020]. 